\title{
Editing in Three Movements: Eriugena, Coleridge, Eliot
}

David Greetham ${ }^{\dagger}$

A strange triumvirate. What can Eriugena, Coleridge, and Eliot and the editions in which their work is enshrined have in common for me to bring them here to the closing conference of Ars edendi and then to the commemorative volume? Or, can the differences in the editing of the three inform our sense of the opportunities and challenges yet remaining in scholarly textuality? And, given the musical allusion in my title, is there some way in which each of these authors and their texts can be thought of as separate 'movements' each contributing to the total text (if you like, the harmony) that is editing and textual criticism?

Bearing in mind A. E. Housman's very neat formulation - 'textual criticism is a science, and, since it comprises recension and emendation, it is also an art. It is the science of discovering error in texts and the art of removing it,' ${ }^{\text {- }}$ - can all three authors and the editions of their works fit comfortably in the art/science dichotomy that we have inherited from Housman? Of course, the conference and the organisation sponsoring it, Ars edendi, recognize just one element of Housman's formulation, the 'arts' of editing, but perhaps for the moment it will suffice to recall that Housman's balanced formula was offered as a corrective to the Germanic dominance of Altertumswissenschaft and the imposition of a strict philology that left little room for the 'thought' in Housman's title. We have to remember that, based on a strict application of recen-

On account of illness this lecture was not delivered by the author but read by one of the Ars edendi members at the concluding conference I7 August, 2016. In the final stages of editing this volume we received the sad news that David Greetham had passed away.

' A.E. Housman, 'The Application of Thought to Textual Criticism', Proceedings of the Classical Association, I8 (I92I), 67-84, p. 68.

How to cite this book chapter:

Greetham, D. 2020. Editing in Three Movements: Eriugena, Coleridge, Eliot. In: Kihlman, E. and Searby, D. (eds.). Ars Edendi Lecture Series. vol. V. Pp. Io9-I22. Stockholm: Stockholm University Press. DOI: https://doi.org/Io.I6993/bbd.g. License: CC-BY 
sio, Lachmann could claim that he could reconstitute not just the text but also the folio breaks in the manuscript archetype of Lucretius $D e$ Natura Rerum. Lachmann's i 850 edition of Lucretius demonstrated to his satisfaction that this archetype contained 302 pages of 26 lines per page and that this in turn was a copy (no longer extant) of a manuscript written in a minuscule hand, derived itself from a copy of a fourth-fifth-century manuscript written in rustic capitals. ${ }^{2}$

In the face of such sureties, Housman was very concerned that editors had been 'readily duped by [...] scientific criticism or critical method', ${ }^{3}$ and that the Germans had mistaken textual criticism for mathematics. ${ }^{4}$ His promotion of 'thought' could be seen, if you like, as an early example of English compromise in the face of Teutonic System.

But why, indeed, these three authors and their texts? All three are representative of recent editing of documents from three periods - late classical, romantic, and modern. The edition of Eriugena by Édouard Jeauneau was published in $1996,5^{5}$ the Coleridge by J.C.C. Mays in $2001,{ }^{6}$ and the Eliot by Christopher Ricks and Jim McCue in $2015 .{ }^{7}$ As a group, they thus embody current theories and practices of the late twentieth and early twenty-first century. And while the methods and principles vary a good deal, all three stand at the end of a long tradition of editing in their respective fields and all three aim to provide a comprehensive, indeed exhaustive, access to the extant documents of their authors. This can be immediately seen in the range and sheer heft on display in the texts of Eriugena, Coleridge, and Eliot.

The Jeauneau edition of Eriugena's Periphyseon runs to five sturdy volumes, for a total of 3293 pages, often with multiple parallel texts, where blank spaces indicate a gap in the text of that witness. The Mays edition of the Poetical Works of Coleridge occupies four volumes of the poetry in section sixteen of the Bollingen Complete Works of Coleridge,

${ }^{2}$ K. Lachmann, In T. Lucretii Cari De rerum natura libros commentarius (Berlin: Georg Reimer, I 850 ).

3 A.E. Housman, Selected Prose, ed. by J. Carter (Cambridge: Cambridge University Press, I96I), p. 37 .

${ }_{4}$ Cf. Housman, Selected Prose, p. I32.

5 Iohannis Scotti seu Eriugenae Periphyseon: editionem novam a suppositiciis quidem additamentis purgatam, ditatam vero appendice in qua vicissitudines operis synoptice exhibentur, ed. by É. Jeauneau, 5 vols, CCCM I6I-I65 (Turnhout: Brepols, I996-2003).

${ }^{6}$ The collected works of Samuel Taylor Coleridge 16: Poetical Works I: Poems (Reading Texts); Poetical works II: Poems (Variorum Texts), ed. by J.C.C. Mays (Princeton, NJ: Princeton University Press, 200I).

7 The Poems of T.S. Eliot: [the annotated text], ed. by C. Ricks and J. McCue, 2 vols (London: Faber, 201 5). 
with two volumes of a 'reading text' and two volumes of a 'variorum text', for a total of 2800 pages, in which, for example, The Rime of the Ancient Mariner takes up thirty-five pages of text historical collation, and notes; and while the Ricks and McCue Eliot seems almost abstemious with a mere 667 pages just on Practical Cats, and I 3 I I pages on Collected and Uncollected Poems, the three publications cannot avoid being labelled monumental. These are weighty tomes, and it is unlikely that they will be superseded any time soon by rival editorial projects.

Given these determinations and uncertainties, can we find any cultural logic in regarding my first author, Johannes Scottus Eriugena, the ninth-century Irish philosopher, as emblematic of the early medieval period; Coleridgean plenitude as appropriate for the Romantic period, and the recent Eliot edition (as distinct from the Eliot corpus) for early twenty-first century textuality?

There is one immediate distinction that can be seen and that is important in the recent history of editing: that the Eliot edition exists at all is a reflection of the often fraught relations between the estates of modernist authors (notably Joyce, Laurence, and Eliot) and scholarly editors. Jonathan Bate records that '[f]or forty years the Eliot estate, in the form of the poet's widow, rigorously restricted quotation and limited cooperation with scholars, ${ }^{8}$ leading Peter Ackroyd to explain in his biography, that 'I am forbidden by the Eliot estate to quote from Eliot's published work,' a restriction that Bate believes largely explains 'why Eliot's reputation took such a severe battering over the decades around the turn of the century.' ${ }^{\prime}$ Clearly, there were no such restrictions placed on the editing of the texts of Eriugena or Coleridge, so there was a celebratory mood about the Ricks and McCue edition of Eliot, a mood that was appropriate for the concluding conference of Ars edendi.

First, let us examine the format of these three editions. In an earlier discussion of Jeauneau's edition of Eriguena for a special commemorative issue of the American Catholic Philosophical Quarterly, ${ }^{\mathrm{II}} \mathrm{I}$ made much of the fact that Jeauneau reflected a current concern with a 'rolling' postmodernist text in which the lure of the 'definitive' had been replaced by an 'open' edition in qua uicissitudines operis synoptice exhibentur, an exemplification of Bernard Cerquiglini's L'éloge de la

${ }^{8}$ J. Bate, 'Fair enough?', The Times Literary Supplement, 6 August, 2010, I4-I 5, p. I 5.

9 P. Ackroyd, T.S. Eliot (London: Hamilton, I984), p.Io.

Io Bate, p. I 5 .

${ }^{11}$ D. Greetham, 'Édouard Jeauneau's Edition of the Periphyseon in Light of Contemporary Editorial Theory', American Catholic Philosophical Quarterly 79 (Fall 2005), 527-548. 
variante: Histoire critique de la philologie (Paris: Seuil, I989), and is to be compared with the immediately precedent edition by I.F. SheldonWilliams, a volume in the series Scriptores Latini Hiberniae, in which the assertion (desideratum? hope? illusion?) was that 'the present edition attempts to present the text with which the author finally came to be satisfied, and at the same time to exhibit the stages of its development, through the creation of a "positive apparatus criticus". ${ }^{\mathrm{I} 2}$ Such desires for 'satisfaction' (the 'making complete' of a work as it progresses toward that most thorny of contemporary textual states, 'authorial final intention'), move Sheldon-Williams's edition in an epistemological direction in the reverse of Jeauneau. Similarly, the desire to construct a 'positive' apparatus (again, for the sake of 'fullness') and the expressed confidence that the 'scribal blunder' can be effectively distinguished from authorial idiosyncrasy are both evidence for the movement in the opposite direction of Jeauneau. Where Sheldon-Williams aims for teleology and completion, authorial and transmissional, the proliferation of textuality in the Jeauneau edition (what we might see as counterpoint or polyphony) sets out the 'critical' edition as only one state in the presentation of textual variation, and allows the 'synoptic apparatus' to become the 'fullest' part of the editorial enterprise (that is, four of the five volumes). Furthermore, what Sheldon-Williams hopefully enlists as a 'positive apparatus criticus' is nonetheless in his edition put in a conventional 'inferior' textual space, in reduced type at the bottom of the page, so that its positivism is in fact a mark of its degenerative status, again a conventional assumption. On the contrary, by freeing the synopticism from this mark of the 'inferior' and placing 'Versiones I-II, Versio II, Versio III, Versio IV, and Versio V' in a visual and spatial equality with one another (and by implication, with the 'critical' edition that sets the whole procedure in motion) Jeauneau forcibly moves the readerly eye (or ear) away from the plainchant of a single utterance into a polyphony with multiple voices and variance as a normative condition.

Thus, while he may be working from basically the same raw materials as Sheldon-Williams (no new witnesses of any significance have appeared of late, and Jeauneau's description of the redactions of Periphyseon is not substantially different from that of his immediate

${ }^{\text {I2 }}$ I.P. Sheldon-Williams, ed., Iohannis Scotti Eriugenae Periphyseon, 4 vols, Scriptores Latini Hiberniae 7, 9, II, I3 (Dublin: Dublin Institute for Advanced Studies, I968-I995). 
predecessor), Jeauneau holds the earlier editorial aims of 'satisfaction' and 'fullness' in abeyance, if they are accorded any value at all, in the face of textual fragmentation and proliferation. It is in the section of Jeauneau's editorial introduction designated as 'Les remaniements du Periphyseon' that the methodological and even ideological distance from Sheldon-Williams's ‘satisfaction' is clearly marked:

Le Periphyseon nous a été transmis sous différentes formes, recensions ou versions. L'étude attentive de ces différentes versions nous permet de suivre, au moins en partie, l'évolution de l'œuvre. Nous sommes en présence, non d'un produit fini, mais d'une matière en fusion; non point d'un texte établi et fixé de façon canonique, mais d'un texte en perpétuel devenir. ${ }^{\mathrm{I3}}$

It is in this sense that all the variants, negative as well as positive, contribute to the perpétuel devenir of a text, that, as we have seen, a blank space (indicating a section that is not present in one of the versions) in the Jeauneau is just as much an authoritative variant as is one with a different text, even though it may be disturbing to the reader's navigation. A blank space in the Jeauneau is just as much a presence as is a positive textual variant. In the Eriugena edition for example, there are numerous occasions when the blank space is recorded as a 'negative reading' in one of the texts in parallel display, facing a passage from another version for which there is no equivalent in other witnesses.

And because Jeauneau believes that Eriugena 'se corrigeait constamment, ajoutant, retranchant, modifiant son texte' ${ }^{\mathrm{I} 4}$ (in a manner that, as we shall see, is similar to Coleridge), Jeauneau's edition is the most expansive of the three authors and editions under review, since it aims to record the complete several different versions that cumulatively make up the documentary history of Periphyseon. ${ }^{\text {I5 }}$

Jeauneau's decision to present the texts of Eriugena in facing-page parallel columns does of course place burdens on both the editor and the reader, and such parallel texts are not likely to become popular. The basic problem of creating and negotiating a parallel text is similar to that involved in the 'full score' of music, in which, as Roland Barthes notes, the reader has to negotiate both the horizontal (paradigmatic)

${ }^{13}$ Jeauneau, vol. I, p. xix.

${ }^{14}$ Jeauneau, vol. I, p. xxii.

Is Chaucerians will already be familiar with the device of the parallel text, as can be seen in the F and G versions of the Prologue to the Legend of Good Women, and parallel texts have a long and distinguished history, from Origen's Hexapla and on to the Complutensian Bible. 
sum sanctum Dionisium Ariopagitam singulariter seraphin et cherubin nominantem, praesertim cum et hebreorum et grecorum usus sit singularia et pluralia pro se inuicem ponere. Sed quae est illa uia quae ducit ad lignum uitae, et quod est illud lignum ad quod ducit? Nonne idem ipse filius dei, qui de se ipso loquitur: "Ego sum uia, ueritas et uita"? Quod autem ipse sit lignum uitae, multis diuinae scripturae locis comperitur apertissime, ita ut nullo indigeat testimonio. Multipliciter itaque in hoc loco sanctae scripturae dei uerbi symbolica nomina exaggerata sunt. Nam et cherubin et flammeus gladius uersatilis et uia et lignum uitae appellatur, ut per hoc intelligamus quod ipsum uerbum nunquam nostri cordis obtutibus recedat, et quod semper ad illuminandos nos praesentissimum sit et beatitudinis, quam praeuaricando perdidimus, nusquam nunquam memoriam perdere sinit, ad eandem semper redire nos uolens et, donec id fiat, condolendo suspirans, perque scientiae et actionis perfectos gradus iter quod illuc ducit carpentes nos instigans. "Ignem", inquit, "ueni mittere in terram, et quid uolo nisi ut accendatur?" Sed priusquam de ipso reditu nostrae naturae tractemus, quaedam ex sensibilibus probatissima argumenta, quibus docemur incunctanter credere ipsum futurum esse, sumenda existimo, si tibi uidetur.
350 turum esse comprobetur.

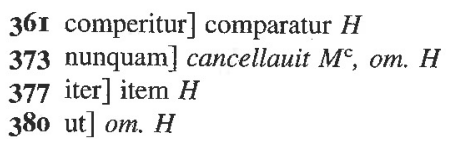

Figure 1: Pages 254-255 in Iohannis Scotti seu Eriugenae Periphyseon: editionem novam a suppositiciis quidem additamentis purgatam, ditatam vero appendice in qua vicissitudines operis synoptice exhibentur, ed. by É. Jeauneau, vol. 5, CCCM I65 (Turnhout: Brepols, 2003), License: CC BY-NC-ND. 
tus nanque sum sanctum Dionysium tus nanque sum sanctum Dionysium

350 Ariopagitam singulariter etiam seraphim et cherubim nominantem, praesertim cum $* * *$ aebraeorum et graecorum usus sit singularia et pluralia pro se inuicem ponere. Sed quae est

illa uia quae ducit ad lignum uitae, et quid est illud lignum ad quod ducit? Nonne idem ipse filius dei, qui de se ipso loquitur: "Ego sum uia et ueritas et uita"? Quod autem ipse sit lignum comparatur apertissime, ita ut nullo indigeat testimonio. Multipliciter itaque in hoc loco sanctae scripturae dei uerbi symbolica nomina exaggerata

365 sunt. Nam et cherubim et flammeus gladius uersatilis et uia et lignum uitae appellatur, ut per hoc intelligauitae, multis diuinae scripturae locis mus quod ipsum uerbum nunquam nostri cordis obtutibus recedat, et quod semper ad illuminandos nos praesentissimum sit et beatitudinis, quam praeuaricando perdidimus, nusquam nunquam memoriam perdere sinit, ad eandem semper redire nos uolens et, donec id fiat, condolendo suspirans, perque scientiae et actionis perfectos gradus iter quod illuc ducit carpere nos instigans. "Ignem", inquit, "ueni mittere in terram, et quid 380 uolo nisi ut accendatur?" Sed priusquam de ipso reditu nostrae naturae tractemus, quaedam ex sensibilibus probatissima argumenta, quibus docemur incunctanter credere ipsum futurum esse, sumenda existimo, si tibi uidetur .
Ariopagitam singulariter seraphim et cherubim nominantem, praesertim cum et aebraeorum et graecorum usus sit singularia et pluralia pro se inuicem ponere. Sed quae est illa uia quae ducit ad lignum uitae, et quid est illud lignum ad quod ducit? Nonne idem ipse filius dei, qui de se ipso loquitur: "Ego sum uia, ueritas et uita"? Quod autem ipse sit lignum uitae, multis diuinae scripturae locis comperitur apertissime, ita ut nullo indigeat testimonio. Multipliciter itaque in hoc loco sanctae scripturae dei uerbi symbolica nomina exaggerata sunt. Nam et cherubim et flammeus gladius uersatilis et uia et lignum uitae appellatur, ut per hoc intelligamus quod ipsum uerbum nunquam nostri cordis obtutibus recedat, et quod semper ad illuminandos nos praesentissimum sit et beatitudinis, quam praeuaricando perdidimus, nusquam nunquam memoriam perdere sinit, ad eandem semper redire nos uolens et, donec id fiat, condolendo suspirans, perque scientiae et actionis perfectos gradus iter quod illuc ducit carpentes nos instigans. "Ignem", inquit, "ueni mittere in terram, et quid uolo nisi ut accendatur?" Sed priusquam de ipso reditu nostrae naturae tractemus, quaedam ex sensibilibus probatissima argumenta, quibus docemur incunctanter credere ipsum futurum esse, sumenda existimo, si tibi uidetur.

352 aebraeorum] scripsi, aebraceorum $F$, ebreorum $J P$ 356 quid] quod $P^{\mathrm{c}}$

357 se] om. $J$ 378 carpere] $F^{\mathrm{c}} P$, capere $F^{* J}$ 380 accendatur] accedatur $J$ 
for melody and the vertical (syntagmatic) for harmony. ${ }^{16}$ The reader confronted by such a 'full score' has to work in two modes, scanning down one text until a 'gross constituent'(in the terminology of structuralism) unit has been recognized and then moving across the page break to compare the gross constituent unit with a similar unit across the page example from Jeauneau. The movement downwards can be regarded as a search for harmonics, in a full score, and the horizontal movement a serial or narrative manoeuvre. A parallel text display works best when there is a basic accord in substantial units of a text, but not so much to obscure variation within a text or specific document.

As an experiment, a while back I constructed a parallel text based on the 1805 and 1850 versions of Wordsworth's Prelude, in which I attempted to show the complex (and not necessarily linear) relations between the two states. ${ }^{17}$ If the result is indeed a 'full score' it is a score in which elements duplicate each other, interrupt across the 'bar of difference,' and continually prevent a neat resolution of the harmonics. Such an interrupted score is to be seen in the five substantive versions of Eriugena.

Coleridge shares with Eriugena an almost obsessive involvement with change and revision. Indeed, Jack Stillinger adopts Coleridge as the type of the revising author, with an antitype in Keats, who very rarely returned to a poem after publication. And in Mays's edition of Coleridge, there is a similar acceptance of plenitude, reflecting the editor's view of Coleridge's composition techniques; 'Coleridge's mind operated at several levels, in several ways, and moved easily between them. An edition should display - not obscure - the variety and vitality of his mind working.' ${ }^{\text {'8 }}$ Mays's concentration on 'Coleridge's mind' is partly a reflection of the earlier Anglo-American intentionalism and partly an attempt to show that mind as it negotiates various social pressures, some quite intimate. Mays argues that '[a]n edition that displays Coleridge's working brain cannot use a "strictly synoptic procedure" because that won't do in charting that mazy mind, where "deliberation alternates with chance, and different intentions exist side by side" (cxx) or they shift and mutate haphazardly. "There is no clear tendency which

${ }^{16}$ See for instance R. Barthes, Elements of Semiology, transl. by A. Lavers and C. Smith (London, Cape, I967).

${ }^{17}$ D. Greetham, Theories of the Text (Oxford: Oxford University Press, I999), p. 3 I 6-3 I9. [Editor's note: The Oxford University Press does not allow any content to be used under any form of open access license, which is why we have not been able to include an illustrative image of the result of Greetham's experiment.]

${ }^{18}$ Mays, Poetical Works I: Poems (Reading Text), Part I, p. lxxxviii (emphasis added). 
could provide the basis of a rule" (cxxi). ${ }^{\text {I9 }}$ Furthermore, Mays argues that 'Coleridge's materials are unruly. The editor must therefore be, like the poet, "fluid and opportunistic" (xv) and like the reader, "fixed in a permanent state of multiple vision"'. ${ }^{20}$ Even the 'reading text' does not imply finality, for it is often merely that text reflecting 'Coleridge's concern, up to the time he lost interest (as he so often did) (cxlvi). ${ }^{{ }^{2 I}}$ The 'reading text' is simply a device to aid in the charting of variance in the historical collation and the 'variorum text'.

Thus, the insistent revision, according to Stillinger, shows Coleridge as a 'compulsive, wilful, out of control' tinkerer with his texts. ${ }^{22}$ Given what Mays characterizes as Coleridge's 'capaciousness,' with, for example, sixteen versions of the Ancient Mariner, ironically the advocate of 'unity' in poetry may be one of the most 'scattered and disunified poets in English literature.'23 Stillinger speculates that 'perhaps he conspicuously featured his poetry's textual instability in order to imply that his poems were always in progress toward a never-to-be attained but increasingly approached perfection. Perhaps he wished to suggest that the perfect poem is a chimera and that authority itself is therefore a fiction. Perhaps he kept changing his poems to show that he was not dead. ${ }^{24}$ In these circumstances, a multiform edition, like that of Mays, becomes the only honest way of representing Coleridge and his methods of composition.

The poem 'Dejection: An Ode', for example, first appeared in a nascent form in the so-called 'Letter' of I 802 , which Mays insists should be seen as the muddled, unstructured first inspiration, 'never intended for publication.' ${ }^{25}$ The 'reading text' in the Mays edition, because it is clear text, does not allude to this muddle, but simply prints it as poem 289, the 'Letter' containing the stanza 'O Sara! we receive but what we give/And in our Life alone does Nature live,' which becomes 'O Lady' in poem 293 'Dejection: An Ode. ${ }^{26}$ In the 'variorum text,' the very much shortened poem lists an array of dedicatees: 'O Wordsworth,'

19 J. McGann, A New Republic of Letters: Memory and Scholarship in the Age of Digital Reproduction (Cambridge, MA: Harvard University Press, 20I4), p. I I6.

${ }_{20}$ McGann, p. II7.

2I McGann, p. I 18.

${ }^{22}$ J. Stillinger, Coleridge and Textual Instability: The Multiple Versions of the Major Poems (Oxford: Oxford University Press, I994), p. II7.

23 Stillinger, p. I I7, original emphasis.

24 Stillinger, p. I I 7 .

25 Mays, Poetical Works I: Poems (Reading Text), Part 2, p. 677. The poem in this form, called 'A Letter to -', is on pp. 679-69I.

${ }^{26}$ Mays, Poetical Works I: Poems (Reading Text), Part 2, p. 689 and pp.695-702. 
'Edmund,' 'William,' 'Edmund,' and 'Lady.' Coleridge was fortunate that all of these choices are disyllables, none of which would disturb the metrics of the line. ${ }^{27}$

In my correspondence with Mays, he tells me that the 'Letter' is part of the 'circular progression (Sara Hutchinson to Wordsworth in various guises and Edmund for the generic 'poet' - i.e. Spenser) and can be understood as the muddled, unstructured first inspiration reconceived and re-projected as 'Lady', a version of the same imaginative ideal that is at the heart of the poem. ${ }^{28}$ But while the poem, from the 1802 'Letter' to the I8I7 first publication and beyond, may indeed have an 'imaginative ideal that is at the heart of the poem' each of the variant addressees represents a significant part of Coleridge's poetic conception and reconception.

Now, all of this cumulative variance does not completely answer the question already raised of why some authors can never let go of a text and continue to re-enter the text on numerous compositional stages. Just as Beethoven would frequently add another measure to an already engraved score from his publisher, so Coleridge would not regard a print proof as anything but a way-station and not the 'final word'. But it does provide evidence of the 'perpétual devenir' that Coleridge shares with Eriugena.

It would seem that the editors of both the Eriugena and the Coleridge have similar aims: to make available to the reader an enormous corpus of variants; but the methods are very different, Jeauneau opting for a series of parallel texts containing the various authoritative witnesses in full, but without attempting a reading text or a base manuscript for collation. But Mays creates (or selects) a 'reading text' and then provides a full documentary record of variants. It is important to note that the selection of the base manuscript for Coleridge does not confer any specific authority on this witness: it is simply a device to aid in the charting of variance in the historical collation and the 'variorum text'.

As I take titles seriously, I have to believe that Ricks and McCue's decision to call their edition 'the annotated text' rather than a 'critical' text or some such makes a statement about editorial policy and procedures.

${ }_{27}$ Poem 293 in Mays, Poetical works II: Poems (Variorum Texts), p. 890. [Editor's note: Princeton University Press does not allow any content to be used under any form of open access license, which is why we have not been able to include illustrative images of the different variants of the poem.]

${ }^{28}$ J.C.C. Mays in private correspondence. 
And because it is an 'annotated' edition not a 'critical' edition, the Ricks and $\mathrm{McCue}$ volumes do not present variance in the texts presented.

The Eliot corpus is a relatively invariant body of poetry, partly reflective of Eliot's diffidence about revision. As Ricks and McCue remark: 'Although Eliot was reluctant to revise after publication, examination has shown that even repeated impressions of the same edition diverge to an unexpected extent.' ${ }^{29}$ Variance exists in despite of authorial intention. Eliot is equally aggrieved about the state of his first editions: 'I have never succeeded in getting a first edition of one of my own books printed without some errors in it, and I sometimes find that when those are corrected new errors appear.' ${ }^{30}$

Why does this distinction of purposes and practice matter in this discussion of Eriugena, Coleridge, and Eliot? As has already been shown, the five volumes of Eriugena, displaying a vast array of texts and variants, fall in line with the usual procedures of the 'literary' editions, though we should be very clear that the accumulated evidence of these five volumes is not put in service of the establishment of a singular, authoritative text. Each of the versions recorded is given unique and specific authority and is not subordinated to the support of a 'critical' or 'eclectic' text. At best, they might be likened to Leitmotifs recognizable in various parts (and versions) of a musical text, but not establishing a specific authority. Or, they might be the variations (like Beethoven's Diabelli, Elgar's Enigma, or Bach's Goldberg) without the theme to which they would usually relate. The Coleridge is different, depending on where you look. The volumes of the 'variorum text' in the Coleridge consist entirely of the variants (there is no 'standard' text to which they can be compered), whereas the 'reading text' provides precisely that, a clear-text presentation of an editorially preferred text, unencumbered by the sort of record of variance in the 'variorum text.'

The Eliot volumes have a clear text up front (the equivalent of the 'reading text' in the Coleridge), followed by a series of interpretative texts recording the documentary history and a commentary which is the basic rationale for the edition, announcing itself as the 'annotated text.'

The Eliot edition is not immune from the sort of incorrigible error that often plagues standard editions, as when the last line of Part II ('with eyes I dare not meet in dreams') of 'The Hollow Men' is repeatedly omitted in several subsequent editions.

29 Ricks and McCue, vol. I, p. xii

$3^{\circ}$ Letter to Djuna Barnes I 5 Oct I936, quoted in Ricks and McCue, vol. I, p. xii. 
Similarly, the error in the dedication to Jean Verdenal in 'Prufrock' (I889 instead of I 890) is retained, although the mistake was acknowledged by Eliot, on the grounds that 'the dedication has stood for almost a century and it has been thought best not to alter it ${ }^{{ }^{\prime}{ }^{1} \mathrm{I}}$ an argument that might seem to support the 'socialization' of the text or could be put down to editorial weariness.

Eliot was in general receptive to Pound's advice: 'He cut out a lot of dead matter. I think that the poem as originally written was about twice the length. It contained some stanzas in imitation of Pope, and Ezra said to me "Pope's done that so well that you had better not try to compete with him" which was sound advice'. ${ }^{32}$ Actually, Eliot's memory has exercised a little self-censorship, for Pound's intercession was less delicate than 'not try to compete'. What he actually warned Eliot was that 'you cannot parody Pope unless you can write better verse than Pope - and you can't.'33

Perhaps the most striking example of divergence between published text and drafts is the opening page for the 1922 Waste Land versus the 'same' text in the 'editorial composite'. ${ }^{34}$ Thus, we would not know from the clear text that the original title for the poem was 'He do the police in different voices' (a quotation from Dickens, Our Mutual Friend, bk I, ch. xvi), ${ }^{35}$ though this reading is confirmed in the facsimile edition containing Eliot's original typescript or manuscript, Pound's annotations and the very occasional marginal comment by Vivienne Eliot ('Wonderful'). ${ }^{36}$ The decision to omit any reference to pre-publication manuscript readings in Ricks and McCue is, if you like, a very powerful example of a 'final intentions' ideology, privileging later print over manuscript draft. It does not take much imagination to speculate on the likely social and canonical status of the poem if it were still called 'He do the police', and is another example of the importance of titles.

But there is more to it than just the title. We should not imagine that there is a linear progression from the so-called 'manuscript' to the print

${ }^{31}$ Ricks and McCue, vol. I, p. xiii.

${ }^{22}$ Ricks and McCue, vol. I, p. 58 I.

33 T.S. Eliot, The Waste Land: A Facsimile and Transcript of the Original Drafts, Including the Annotations of Ezra Pound, ed. by Valerie Eliot (London: Faber and Faber, I97I), p. I27.

34 Ricks and McCue, vol. I, pp. 55-7I (published text), and pp. 324-346 (editorial composite). [Editor's note: Images of these pages have not been possible to include here since we could not obtain an Open Access license from Faber \& Faber.]

35 Ricks and McCue, vol. I, p. 324.

${ }^{36}$ Eliot, The Waste Land: A Facsimile, pp. Io-I I. [Editor's note: Images of these pages have not been possible to include here since we could not obtain an Open Access license from Faber \& Faber.] 
edition of 1922. For example, the passage beginning 'the typist home at teatime' occurs twice in the manuscript in very different contexts and in one such is the occasion for some of Pound's more caustic comments ('perhaps be damned', 'Make up your mind' and 'inversions not warranted by any real exegience [sic] of metre.'). ${ }^{37}$ While Eliot was generally very receptive to the sort of revisions suggested by Pound; 'the typist' section, despite its dual prominence in the manuscript, is not carried forth into 1922, which remains the de facto terminus for the evolution of the poem and is thus very different from the sort of variance encountered in Eriguena and Coleridge.

This potted history now means that I have to retract my earlier assumptions that the sheer weight of these three editions would mean that editing now stops. In fact, it might very well be the exact opposite: that the availability of the texts in these forms will encourage further textual examination based on the new information (specifically for Eliot). But there is another factor: before embarking on this investigation, I had worked on several previous editorial projects, separate from my writings on textual and editorial theory and history. These had included work on a) the collaborative edition of John Trevisa's On the Properties of Things, the fourteenth-century encyclopedia of, well, everything, in which the aim was to reconstruct the archetype lying behind and above the extant manuscripts, and b) the editing of Thomas Hoccleve's Regement of Princes, through the construction of an idiolect drawn from the practices in several autograph manuscripts of other Hoccleve's works. Neither of these projects is in any way similar to the conditions of the documents encountered in Eriugena, Coleridge, and Eliot, so I have learned a great deal in doing the research for this paper. The one underlying principle has been, and will continue to be, fidelity to the author, who, despite the dire claims of Roland Barthes, is very much alive, but alive through the loyalties and devotions (and sheer hard work) of editors working in the long tradition extending from the Alexandrian librarians to the present day. It is perhaps in this sense of a long tradition that I see these loyalties and devotions so much evident in the range and enthusiasms of this conference, and I am very grateful to have been able to add to these enthusiasms in working on this paper. I am now in a different place from before I started work on this report and thank you all for giving me the opportunity to demonstrate what I have learned from this experience.

37 Eliot, The Waste Land: A Facsimile, pp. 44-45. 


\section{Bibliography}

Ackroyd, P., T.S. Eliot (London: Hamilton, I984).

Barthes, R., Elements of Semiology, transl. by A. Lavers and C. Smith (London, Cape, I967).

Bate, Jonathan, 'Fair enough?', The Times Literary Supplement, 6 August (20IO), I4-I 5 .

Eliot, T.S., The Waste Land: A Facsimile and Transcript of the Original Drafts, Including the Annotations of Ezra Pound, ed. by Valerie Eliot (London: Faber and Faber, I97I).

Greetham, D., Theories of the Text (Oxford: Oxford University Press, I999).

Greetham, D., 'Édouard Jeauneau's Edition of the Periphyseon in Light of Contemporary Editorial Theory', American Catholic Philosophical Quarterly, 79 (Fall 2005), 527-548.

Housman, A.E., 'The Application of Thought to Textual Criticism', Proceedings of the Classical Association, I 8 (I92I), 67-84.

Housman, A.E., Selected Prose, ed. by J. Carter (Cambridge: Cambridge University Press, I96I).

Jeauneau, É., ed., Iohannis Scotti seu Eriugenae Periphyseon: editionem novam a suppositiciis quidem additamentis purgatam, ditatam vero appendice in qua vicissitudines operis synoptice exhibentur, 5 vols, CCCM I6I-I 65 (Turnhout: Brepols, I996-2003).

Lachmann, K., In T. Lucretii Cari De rerum natura libros commentarius (Berlin: Georg Reimer, I 850$)$.

Mays, J.C.C., ed., The Collected Works of Samuel Taylor Coleridge I 6: Poetical Works I: Poems (Reading Texts) 2 vols; Poetical Works 2: Poems (Variorum Texts) 2 vols (Princeton, NJ: Princeton University Press, 200I).

McGann, J., A New Republic of Letters: Memory and Scholarship in the Age of Digital Reproduction (Cambridge, MA: Harvard University Press, 2OI4).

Ricks, C. and J. McCue, eds, The Poems of T.S. Eliot: [the annotated text], 2 vols (London: Faber, 20 I 5 ).

Sheldon-Williams, I.P., ed., Iohannis Scotti Eriugenae Periphyseon, 4 vols, Scriptores Latini Hiberniae 7, 9, II, I3 (Dublin: Dublin Institute for Advanced Studies, I968-I995).

Stillinger, J., Coleridge and Textual Instability: The Multiple Versions of the Major Poems (Oxford: Oxford University Press, I994). 